\title{
Implementation of the Ecosystem Services Approach in a Swedish
}

\section{Municipality}

Per Schubert ${ }^{\mathrm{a}}$, Nils G. A. Ekelund ${ }^{\mathrm{a}}$, Thomas H. Beery ${ }^{\mathrm{b}}$, Christine Wamsler ${ }^{\mathrm{c}}$, K.

Ingemar Jönsson ${ }^{\mathrm{d}}$, Andreas Roth ${ }^{\mathrm{a}}$, Sanna Stålhammar ${ }^{\mathrm{c}}$, Torleif Bramryd ${ }^{\mathrm{e}}$,

Michael Johansson ${ }^{\mathrm{e}}$, Thomas Palo ${ }^{\mathrm{f}}$

${ }^{a}$ Science, Environment and Society, Malmö University, SE-205 06 Malmö, Sweden;

${ }^{b}$ Minnesota Sea Grant, University of Minnesota Duluth, Duluth, Minnesota, United States

55812; ' Lund University Centre for Sustainability Studies, Lund University, SE-221 00 Lund,

Sweden; ${ }^{d}$ School of Education and Environment, Division of Natural Sciences, Kristianstad

University, SE-291 88 Kristianstad, Sweden; ${ }^{e}$ Environmental Strategy, ISM, Lund University,

Campus Helsingborg, SE-251 08 Helsingborg, Sweden; ${ }^{f}$ Department of Wildlife, Fish and

Environmental Sciences, Swedish University of Agricultural Sciences, SE-901 83 Umeå,

Sweden

${ }^{*}$ Science, Environment, Society, Malmö University, SE-205 06 Malmö, Sweden,

+46.72.5557490, per.schubert@mah.se 


\title{
Implementation of the Ecosystem Services Approach in a Swedish
}

\section{Municipality}

\begin{abstract}
While ecosystem-based planning approaches are increasingly promoted through international and national policies, municipalities are still struggling with translating them into practice. Against this background, this paper aims to increase knowledge of current advances and possible ways to support the implementation of the ecosystem services approach at the municipal level. More specifically, we analyze how services provided by ecosystems have been integrated in comprehensive planning within the municipality of Malmö in Sweden over the last 60 years, a declared forerunner in local environmental governance. Based on a content analysis of comprehensive plans over the period 1956-2014 and interviews with municipal stakeholders, this paper demonstrates how planning has shifted over time towards a more holistic view of ecosystem services and their significance for human well-being and urban sustainability. Both explicit and implicit applications of the ecosystem service concept were found in the analyzed comprehensive plans and associated programs and projects. Our study shows how these applications reflect international, national, and local policy changes, and indicates how municipalities can gradually integrate the ecosystem services approach into comprehensive planning and facilitate the transition from implicit to more explicit knowledge use.
\end{abstract}

Keywords: comprehensive planning; ecosystem services; ecosystem service concept; municipal planning; urban planning 


\section{Introduction}

Increasing urbanization requires increased knowledge and understanding of ecosystem-based planning approaches (Folke et al., 1997; Haase et al., 2014). Today, 54\% of the world's and $76 \%$ of Europe's population live in urban areas (The World Bank, 2016), and about $70 \%$ of the world's population is expected to be urban in 2050 (UN-Habitat, 2012). Urban populations depend on a variety of ecosystem services (ES) from both urban and rural systems, such as food production, maintenance of clean air, recreation opportunity, and carbon dioxide sequestration (Folke et al., 1997; Millennium Ecosystem Assessment, 2005; Niemelä et al., 2010). However, limited vegetation structures and green areas within urban areas may restrain species diversity and ecosystem stability, and therefore, the production of ES (Fahrig, 2002; Loreau \& de Mazancourt, 2013; MA, 2005). Although considered as an important environmental policy concept (MA, 2005; Portman, 2013), insufficient attention has been given to ES in urban planning (Luederitz et al., 2015; Wilkinson, Saarne, Peterson, \& Colding, 2013), and planners are struggling with integrating the ES approach into practice (Beery et al., 2016; Böck, S. Muhar, A. Muhar, \& Polt, 2015; Gupta, 2015; Wamsler, 2015; Wamsler, Luederitz, \& Brink, 2014). Further progress is required for the approach to be fully integrated into relevant institutions, such as clear operational guidelines (Beery et al., 2016), ways to quantify and value ES (de Groot, Alkemade, Braat, Hein, \& Willemen, 2010), and cross-landscape assessments methods (Portman, 2013).

Benefits of natural ecosystems have been recognized in many earlier publications (e.g., Helliwell, 1969; Ryther, 1969), and ES gained prominence in the early 1980s (Portman, 2013). Following breakthrough publications such as Nature's services (Daily, 1997), the ES approach became important news in ecosystem economics in the late 1990s (Portman, 2013). Daily defines ecosystem services as 'the conditions and processes through which natural ecosystems, and the species that make them up, sustain and fulfill human life' (Daily, 1997: p. 
3) while the Millennium Ecosystem Assessment (MA) defines them as 'the benefits people obtain from ecosystems' (MA, 2005: p. V). In this study, we include both the biotic and abiotic benefits that people obtain from natural as well as human-managed ecosystems. Like MA (2005), we are classifying these services into the supporting, provisioning, regulating, and cultural categories, being aware that this system has been criticized for mixing ends (ES) with means (i.e., supporting services) (Wallace, 2007). The MA framework was adopted by The Economics of Ecosystems and Biodiversity (TEEB), a global initiative focused on capturing the value of nature and its integration into decision-making, which was launched in 2007 by the German Federal Ministry for the Environment (BMUB) and the European Commission (EC) (The Economics of Ecosystems and Biodiversity, 2016). In Sweden, the government has adopted the MA framework at the national level and instituted a milestone target within the national environmental quality objectives, stating that ES should be generally known and implemented in societal decision-making and planning processes by 2018 (Swedish Government Official Reports, 2013). Since Swedish municipalities have the major responsibility for urban planning, they will play a central role in achieving this milestone target.

Studies made within the Swedish urban green infrastructure and ES planning context have focused on analyses of policies and strategic plans and interviews with stakeholders. Within the Swedish context, Sandström (2002) identified recreation as the most important criterion for the role and value of green space in green infrastructure plans from seven Swedish cities over the period 1993-2001. Sandström, Angelstam, and Khakee (2006) show that urban planners from six large Swedish cities expressed an interest in maintaining biodiversity but were limited by insufficient knowledge and organization. Wilkinson et al. (2013) demonstrate a common increasing ES trend in 1936-2010 comprehensive plans from Stockholm, but with a considerable variation over time in the specific ES referred to in the 
plans. A recent study by Beery et al. (2016) shows that southern Swedish municipal stakeholders generally have a positive view on the ES concept, its usefulness, and monetary ES valuation, but also that clear definitions and operational guidelines are needed to support implementation of the ES approach.

Against this background, the aim of this paper is to increase the knowledge on current advances and possible ways to support the implementation of the ES approach at the municipal level. More specifically, we assess how services provided by ecosystems have been integrated in urban planning within the Swedish municipality of Malmö by identifying and

analyzing explicit and implicit applications of the ES concept in comprehensive plans over the last 60 years as well as associated stakeholders' perceptions on the implementation of the ES approach. Here we define an explicit application or implementation as indicating a conscious understanding of the ES concept and an implicit application or implementation as indicating a conceptual understanding of nature's services without associating this understanding with the ES concept itself (Hauck, Görg, Varjopuro, Ratamäki, \& Jax, 2013; Wilkinson et al., 2013; Matzdorf \& Meyer, 2014; Hansen et al., 2015; Beery et al., 2016).

\section{Methodology}

\section{Study case}

Our case study of Malmö municipality was conducted as part of a larger research project titled Implementing the Ecosystem Services Approach at the Municipal Level (ECOSIMP) (Jönsson et al., 2017). This project was developed in close collaboration with seven volunteering coastal municipalities in Scania, which is the southernmost administrative region of Sweden. These municipalities are of special interest since they are located along the western coastline facing the Sound and the southern and eastern coastlines facing the Baltic Sea. This location exposes these municipalities to a range of environmental challenges within various coastal 
socio-ecological contexts, including growing urbanization, nutrient flow from land to the sea, and increased pressure on coastal zones from rising sea levels (Centre for Climate Adaptation, 2015; HELCOM, 2009; Larson \& Hanson, 2013; Rauhut, 2008).

This study was developed in close collaboration with Malmö municipality ${ }^{1}(328,494$ inhabitants 31 December 2016, see Malmö City, 2016a), which is an internationally recognized forerunner in local environmental governance (Lenhart, Bouteligier, Mol, \& Kern, 2014; Malmö City, 2016b). Since the late 1980s when Malmö’s key industries collapsed, such as ship building, the city has been undergoing a transition from being an industrial city to become a city of knowledge and sustainability (Environmental Programme, 2009; Lenhart et al., 2014). The construction of Malmö University, Öresund Bridge (connecting Malmö with Copenhagen), and Bo01 (Sweden's first city area with climate-neutral energy systems) initiated this transition. Older industry is being replaced by investments in new technology to solve environmental problems and to develop a sustainable city. Over the last years, Malmö municipality has received many international awards for its focus on environmental and sustainable city development, for example, European Commission's 2012 RegioStars Award for integrated sustainable development strategies in vulnerable urban areas (Lenhart et al., 2014; Malmö City, 2016b).

\section{Data collection and analysis}

\section{Comprehensive plans}

Swedish municipalities employ planning tools at different levels, such as a comprehensive plan and detailed plans, where the comprehensive plan indicates the overall direction of the societal development and therefore guides the detailed planning processes. In close collaboration with Malmö municipality, all available comprehensive plans over the period 1956-2014 were collected for a content analysis (Table 1). 
[Table 1 near here]

Both explicit and implicit text references to the ES concept in these plans (including figure and table captions) were assessed (cf. Bryman, 2011; Wilkinson et al., 2013). An explicit text reference is a text part that explicitly use the ES concept, indicating a conscious understanding of the ES concept. An implicit text reference is a text part that implicitly use the ES concept, indicating a conceptual understanding of nature's services without associating this understanding with the ES concept itself (Beery et al., 2016; Hansen et al., 2015; Hauck et al., 2013; Matzdorf \& Meyer, 2014; Wilkinson et al., 2013). An overall qualitative contextual evaluation of prominent concepts and expressions in the comprehensive plans was conducted. This evaluation also supported the quantitative analysis (i.e., counting) of ES-related concepts, which are implicit references not explicitly linked to the ES concept (Table 2).

[Table 2 near here]

The identified ES-related concepts were classified into supporting, provisioning, regulating, and/or cultural categories/services (MA, 2005), based on a supportive qualitative reading of the contexts. Trends over time were analyzed by determining for each comprehensive plan (1) the total number of ES-related concepts, (2) the total number of times each ES category is represented, (3) the average number of ES-related concepts per page (to take into consideration the different lengths of the analyzed plans), and (4) the average number of times per page each ES category is represented. For this analysis, the following rules were applied:

- A concept was counted if it could be interpreted as implicitly expressing an ES.

- Each ES-related concept was counted and classified only once, regardless of the different contexts within which it was found. 
- Also closely related concepts were counted as separate concepts (e.g., biological production and biological reproduction).

- The classification of a concept into the ES categories (supporting, provisioning, regulating, and/or cultural) was nonexclusive, allowing a single concept to be classified into more than one category at the same time.

To improve the reliability of this study, three researchers (coders) completed the content analysis in parallel: 1) Inter-coder reliability was developed and tested throughout the process by comparing results of interpretation; 2) Observed differences were discussed and corrected (a consensus alignment); and 3) These on-going comparisons between coders revealed no major differences.

\section{Interviews}

Within the ECOSIMP project, 36 individual municipal stakeholders were interviewed in seven coastal municipalities in Scania. Purposeful and chain sampling were used to select the interviewees, as being municipal civil servants and politicians who are (or have been) involved in ES planning. Based on a discussion with a project advisor at Malmö municipality, participants were selected to represent key roles for municipal planning and ES implementation. This process accounted for important roles of proactive civil servants regarding municipal environmental planning efforts (Roberts, 2010). The nine chosen interviewees were all involved in planning processes and represent a range of occupations: two environmental strategists, one landscape architect, two planning architects, one planning ecologists, one project manager, and two commissioners (politicians serving at the municipal level). The interviews were used in this study to complement the content analysis with deeper 
qualitative interpretations of the identified changes and use of the ES approach in municipal planning.

The nine interviews were performed between December 2014 and March 2015, using a semi-structured interview method with predefined questions (Appendix A). The interview format maintained adherence to predefined questions with flexible prompts allowing for individualized follow-up. Each interview was recorded with interviewee permission and transcribed for data analysis purposes. Given the relative novelty of the ES concept in municipal planning, in-depth and/or homogenous knowledge on the concept was not assumed. Therefore, at the beginning of each interview, definitions of ES and illustrative figures from Sweden's Environmental Objectives (The Swedish Environmental Protection Agency, 2015) and the MA as well as the Swedish milestone target were briefly presented.

Analysis of interview data consisted of a grounded theory process of initial coding, focused coding, and thematic coding (Charmaz, 2006; Charmaz, 2008; Moghaddam, 2006) to identify (the importance of) past developments, barriers, and drivers to implement the ES approach in municipal planning. Specialized software for the analysis of qualitative data (ATLAS.ti) was used to facilitate the coding process. Initially, the transcribed material was coded line by line, followed up with focused coding to form clusters and categories. Comparisons between transcribed interviews, codes, clusters, and categories allowed for integration of the material and concepts into themes. Research oversight in this process included data analysis by two researchers; all transcripts were reviewed and coded based on the procedure described above in an on-going comparative effort by both researchers. In addition, the ES knowledge use framework by McKenzie et al. (2014) was used to categorize results of interview question 3, dealing with the application of the concept. For more information on data collection, coding, and categorization, see Beery et al. (2016). 


\section{Results}

\section{Comprehensive plan analysis}

The evaluation of prominent concepts and expressions in the comprehensive plans since 1956 shows a clear change over time, from rather narrow to more holistic (comprehensive and integrated) and systemic (as opposed to narrow) understandings of ecosystems and their services. The following patterns were identified:

- Explicit references to the ES concept are not made until the 2014 comprehensive plan.

- The average numbers of ES-related concepts per page in the plans varies over time with a spike in 1990 and an increase in 2014.

- Provisioning services are the most common ES category and regulating services the least common since 1956.

The ES concept is introduced for the first time in the 2014 comprehensive plan. In a section on the city's green infrastructure and design it is stated:

The profile of Malmö with many parks and green spaces will be strengthened and confirmed with high artistic, architectural, and ecological levels. Parks and squares throughout the city will be developed with high architectural ambitions and further developed as meeting places and arenas for culture, creativity, and various events, at the same time as their roles for urban ecosystem services are developed. New green urban concepts, elements of green roofs, and walls will be promoted for both newly produced and already existing buildings.

The concept is explicitly referred to in three additional sections: Natural resources and values, The sea and coastline, and Water. Here, the ES concept is used both in a general 
conceptual sense, to describe the values of nature, as well as in a more strategic sense (as in the above citation) where considerations of ES in future developments and measures within the municipality are stipulated.

Although there is one main section with an environmental focus in the 1956 comprehensive plan, the ES-related concepts are distributed across the documents from 1956 and 1966. The 1980, 1990, 2000, and 2014 plans have four, six, seven, and eleven environmental chapters or main sections, respectively. Even if this indicates a green trend, it does not necessarily reflect the numbers of ES-related concepts over time, since these depend upon how long the chapters and sections are and to what extent ES-related concepts are discussed in other parts of the documents. The quantitative analysis of the total numbers of ES-related concepts in the comprehensive plans reveals a decrease from 1956 to 1966, a large increase from 1966 to 1990, and thereafter a gradual decrease to 2000 and 2014, where 2014 is about the same level as 1956 and well below 1990 (Figure 1). The numbers of times each ES category is represented follows the same trend over time.

[Figure 1 near here]

As an evaluation of the relative importance of ES-related concepts, the average numbers of ES-related concepts per page in the comprehensive plans follow a similar trend over time with a decrease from 1956 to 1966, a large increase from 1966 to 1990, and thereafter a large decrease to 2000 (Figure 2). In contrast to the total numbers of concepts in Figure 1, there is an increase from 2000 to 2014, where the figure from 2014 is more than two times larger than 1956 but still well below the 1990 figure. The average numbers for each ES category follows the same trend over time. 
[Figure 2 near here]

Based on the average numbers of times per page each ES category is represented in the comprehensive plans, provisioning services stands out as the most common category over the period 1956-2014 (Table 3). Cultural services comes in as a close second while supporting and regulating services come third and fourth. There are trends showing that the frequency of cultural ES-related concepts decrease over time while provisioning ES-related concepts increase.

[Table 3 near here]

\section{Interview analysis}

The following patterns were identified through the analysis of the interviews, based on the coding, clustering, and categorizing of the obtained answers into themes:

- The interviewees acknowledged both explicit and implicit applications of the ES concept in their work.

- The few explicit applications of ES were said to be centered on specific programs and projects within the municipality.

- The interviewees noted that the ES concept is increasingly used, although often not explicitly named as such.

- The concepts of multifunctionality, green infrastructure, and green space factor were noted as important implicit applications.

All interviewees acknowledged both explicit and implicit applications of the ES concept in their work to foster municipal planning and governance. Most of the explicit applications in 
Malmö were said to be centered upon specific programs or projects within the municipality (Table 4 and 5).

[Table 4 near here]

[Table 5 near here]

Examples of such programs are the Environmental Programme for the City of Malmö 20092020 and the Action Plan for the Environmental Programme - Prioritized Work in the City of Malmö 2015-2018, which serve as a common basis for current and future environmental work within the municipality. Regarding the projects, the following interviewee response provides an important example:

[...] we discuss ecosystem services [explicitly] in the biodiversity project [...] and I work with a project called "Care of City" [...] a program entirely focused upon ecosystem services. I also work with a project here in the environmental management division that is called "Mapping and Valuation of Ecosystem Services in Risebergabäcken”.

Another interviewee elaborated on future plans for explicit references to ES:

$[\ldots]$ it is on the discussion level, but $[\ldots]$ our recommendation within the administration is that our conservation program should, clearly, much more clearly include ecosystem services [...], and then also, connect it more to, other programs, the environmental program, the comprehensive plan [...] and not least investment plans. 
Furthermore, two interviewees indicated that the municipality works specifically with internal communication and information to increase the knowledge about ES.

Eight of the nine interviewees also noted implicit applications of ES. This implicit use, starting long before the term ecosystem service was introduced within a professional work context, was well captured by one interviewee who noted: 'I think it is kind of funny, because when a person works with these [environmental] questions, he or she has been considering the specifics [of ES] for a long time. Then suddenly the concept popped up and I thought, oh, what a great concept to describe what I am doing in my work!' Three interviewees described their work as being based on an ES mindset with ES as an underlying theme behind much of their professional work. The interviewees could also relate the implicit use of the ES concept to the ES categories of supporting, provisioning, regulating, and cultural services.

Another interesting result was that the majority of the interviewees saw the idea of multifunctionality as an important implicit application of ES. Seven of the nine interviewees emphasized that multiple needs and demands can be met with ES efforts despite their implicit use: 'In many cases we use ecosystem services, although not defining them as ecosystem services $[\ldots]$ for a number of measures $[\ldots]$ to get synergy effects [...].' This idea of multifunctionality was repeatedly described within the context of serving people and nature, as a mechanism to bridge the often-divided aspects of social services and environmental management. One interviewee discussed, for example, how urban garden projects in Malmö serve to green the city while also bringing people closer and make neighborhoods safer. Another municipal staff member described the new park creation in Hyllie (a Malmö neighborhood) as an important implicit ES application, providing recreation while simultaneously serving storm water management. Another municipal staff added: 'We should not see saving trees as a sacrifice, but rather use nature more actively, for example, to create 
good quality of life for people in the city via clean air, access to nature, and a more resilient city structure.'

The two other implicit applications of the ES concept, which were repeatedly highlighted, were green infrastructure in general and the green space factor in particular. The green space factor is a planning tool or instrument designed to assure a certain level of green infrastructure in housing developments. The tool has been in use in Malmö since 2001 as part of the Bo01 project (Kruuse, 2011; Malmö City, n.d.), which was the first step in transforming 160 hectares of industrial harbor estate into residential homes. Positive outcomes of these projects has resulted in the continued use of the tool in other new housing developments within the city. It was also said that the continuous applications of the green space factor is a recognition that there exists a need for future support of ES-based planning approaches.

Six of the nine interviewees also highlighted the municipality's responsibility to create ES and find creative applications in urban settings. As expressed by one interviewee: 'We have made experiments with green facades [...] and discovered species [of plants] that can better withstand the climate in Scania, enabling us to improve our work [...]'. The interview results indicate that the green space factor is also seen as a potential tool to assist in the creation of ES and associated multifunctionality within the city.

\section{Discussion}

Table 6 shows how the results provide important input for discussing three themes: 1) The historical development of explicit and implicit applications of the ES concept in municipal plans, programs, and projects; 2) The importance of implicit applications as an underlying theme in municipal plans and work procedures; and 3) Possible transition from implicit to more explicit knowledge use. 
[Table 6 near here]

The progression towards a more explicit use of the ES concept in the comprehensive plans was identified to be related to green space planning and nature conservation. For example, the use of more holistic and systemic concepts like green structure and recreation in 1990, biological life cycle and biodiversity in 2000, and ecological production and nature's values in 2014, indicates a shift in the understanding of ecosystems and their importance for human well-being and sustainability. This progression also supports the results of Sandström (2002) who assessed green infrastructure plans over the period 1993-2001 from seven Swedish cities, including Malmö, and found that the two most important criteria for the role and value of green space are recreation and maintenance of biodiversity. Wilkinson et al. (2013) found that recreation and biodiversity were addressed early in Stockholm's 1936-2010 comprehensive plans, which may explain why Stockholm also started early with explicit references to the ES concept in planning documents (Hansen et al., 2015). The majority of Swedish comprehensive plans with explicit identification of ES emerged in 2013-2014 (Hanson et al., 2016), and Malmö seems to have followed the general trend, being situated at the later end, despite its forerunner role in environmental governance and planning. The oldest Swedish comprehensive plan with explicit reference to ES is from 2009, from the city of Göteborg (ibid.). Generally, and independently of their actual years of elaboration, more holistic and systemic views in planning has opened the door for the ES approach and its linkages to sustainable municipal planning and development (Panagopoulos, Duque, \& Dan, 2016).

Context-related aspects and the importance given to certain international and national policies influence deviations from the general trend over time. ${ }^{2}$ Since Malmö’s comprehensive plan from 1956 was the first, it covers many areas, while the 1966 plan focus on traffic issues and infrastructure. This may explain the larger average number of ES-related 
concepts in 1956 compared to 1966 (Figure 2). The following increase from 1966 to 1990 may be explained by the environmental movement, the Swedish natural resources law in 1987, the Brundtland Report in 1987, and preparations regarding the Rio Earth Summit in 1992. In addition, the Swedish legislation was modified after the Rio Earth Summit to pay special attention to sustainability, stressing the importance of, for example, green spaces, biodiversity, and a good living environment (Government bill, 1995; Sandström, 2002). Swedish municipalities were then also recommended to create a green plan with focus on urban green areas and their contribution to human well-being, biodiversity, and sustainability (Sandström, 2002; Swedish Government Official Reports, 1994). The seemingly contradictory reduction in the use of ES-related concepts in comprehensive plans from 1990 to 2000 may be explained by the very broad focus of the 2000 plan, which did not allow mentioning of any details regarding ES-based approaches. The increase from 2000 to 2014 could be a consequence of international environmental efforts, including MA in 2005, TEEB in 2007, and the Nagoya agreements/Aichi goals in 2010, resulting in national and municipal policies with ecosystem perspectives. In addition, the increasing role of ecosystems in municipal climate mitigation and adaptation may have contributed to this increase in 2014 (Elmqvist et al., 2015; Niemelä et al., 2010; Wamsler et al., 2014; Wamsler et al., 2016). In some municipalities, including Malmö, the use of external funding for ecosystem-based adaptation also provided an additional push for ES implementation, revealing the strong interest of municipal staff in this concept. Malmö has been exceptionally successful in this regard, with a high percentage of such externally funded projects (Wamsler, 2015; Wamsler et al., 2016).

The priority given to provisioning services in Malmö's comprehensive plans (Table 3) can be explained by the common need for food, water, and other natural resources, along with the location of Malmö; the municipality is located on very rich soils and surrounded by 
agricultural land. The other priority given to cultural services can be explained by the city's need for increased recreation and spiritual and aesthetic experiences, since only $12 \%$ of the city area is park or natural land (Green Plan, 2003). This supports the conclusion of Sandström (2002) that the key criterion for the role and value of green space in green infrastructure plans from seven Swedish cities, including Malmö, is recreation related to public health and associated availability and quality of parks and other green spaces. Malmö's low priority for regulating services is somewhat worrying, implying a weak focus on associated ecosystems and their processes (cf. MA, 2005). Larondelle, Haase, and Kabisch (2014) suggest that Malmö's location within an agricultural region is the main reason for a minimal importance given to regulating services. Another reason may be that regulating services are less tangible than provisioning services. However, the priority given to supporting services is reassuring, since they are necessary for all other ES (MA, 2005).

The above-described development of the ES approach was confirmed by the interviewees, but references to explicit applications were limited to specific programs and projects (Table 4 and 5). The environmental program together with the action plan forms a common basis for further environmental work within the municipality. Together with other institutions and companies, Malmö coordinated the BiodiverCity project, which developed new ways of increasing green areas and biodiversity to promote urban ES for human health and sustainability. However, within the BEST project, Malmö and other municipalities used interviews and questionnaires to investigate the basis for implementing the ES approach, and results show that only a few of 147 Swedish municipalities include explicit applications in their comprehensive plans (Hanson et al., 2016). The interviewees acknowledged implicit applications as an underlying theme in Malmö's work procedures, and the slow shift to explicit applications, and the associated internalizations of international and national efforts, has also been highlighted by other studies (e.g., Sandström, 2002; Sandström et al., 2006). 
Similar to the Portuguese planning context, the interviewees are familiar with the concept, consider it as important, and are aware of its implicit integration in municipal plans and work procedures (cf. Mascarenhas, Ramos, Haase, \& Santos, 2014).

Beery et al. (2016) introduce the concepts of implicit and explicit knowledge use, which are helpful when reasoning about pedagogical ways of transforming knowledge and its use from being implicit to become explicit. They found that southern Swedish municipal stakeholders generally have a positive view on the ES concept and its usefulness, and that associated knowledge is considered important. They also found that interviewees' emphasis on implicit knowledge use most probably reflect insufficient explicit knowledge use in the municipal work procedures. This supports results from Sandström et al. (2006) indicating that planners experience many barriers when using ES approaches in comprehensive planning, including limited knowledge. To support the transition from implicit to more explicit knowledge use, an increase in ES knowledge and its integration and mainstreaming is crucial. The ES approach is a mainstreaming issue and needs to be integrated into municipal operations, planning, and decision-making (Vignola, Locatelli, Martinez, \& Imbach, 2009; Wamsler et al., 2016). Knowledge of ES and associated concepts and their implicit applications are an important basis for such an integration (e.g., Mascarenhas et al., 2014). To promote Malmö's, and potentially other municipalities', ongoing transitions from implicit to more explicit knowledge use, municipal stakeholders should first be made aware of existing implicit applications and address to what extent they already work from an ESoriented mindset. Increased momentum and more explicit knowledge use in comprehensive planning was noted by interviewees to be fostered by its application in informal plans, projects, and instruments, such as conservation programs, investment plans, and environmental tools and concepts (e.g., the green space factor and multifunctionality). Similarly, ES could be further supported through, for example, tools for mainstreaming 
ecosystem-based climate change mitigation and adaptation (Elmqvist et al., 2015; Niemelä et al., 2010; Wamsler et al., 2014; Wamsler et al., 2016). The latter is crucial, since there is also a need for identifying and promoting the less tangible regulating services within the municipality, given that these services seem to be historically and presently neglected. Regulating services are benefits obtained from the regulation of ecosystem processes (MA, 2005), for instance for climate change adaptation, and additional work to identify such services within different contexts would strengthen the focus on ecosystems and their functioning.

\section{Conclusions}

This study investigated the integration of the ES approach within the Swedish municipal planning context. More specifically, we assessed explicit and implicit applications of the ES concept in Malmö municipality’s comprehensive plans since 1956 along with associated stakeholders' perceptions. Even if case studies have limited generalizability, other studies have shown similar patterns, supporting the relevance of our results beyond this particular case.

Firstly, our results show that planning has shifted over time towards a more holistic understanding of ES in general and particularly how ES can promote human well-being and sustainable development. This was revealed both by explicit and implicit applications of ES in the analyzed comprehensive plans and associated municipal programs and projects. Secondly, the identified trends of ES applications over time reflect international, national, and local policy changes, which result in local deviations from trends at a larger scale. An example is the adoption of the international MA framework as a milestone target within the Swedish national environmental quality objectives. Thirdly, our results indicate ways to expedite the transition from implicit to more explicit knowledge use of ES in comprehensive planning and 
associated municipal work procedures. Although our interviews have shown that most relevant stakeholders seem to be familiar with the ES concept, they also indicated that further support is needed for translating this knowledge into actual implementation. We argue that increased knowledge and awareness of explicit and implicit knowledge use and applications is crucial to support more ES-oriented planning. Such knowledge and awareness can increase the momentum and stimulate further applications in plans, projects, and planning instruments.

\section{Acknowledgements}

The authors wish to acknowledge Tyke Tykesson and Annika Kruuse and other personnel at Malmö municipality for their invaluable input to this study.

\section{Disclosure statement}

No potential conflict of interest was reported by the authors.

\section{Funding}

This work was supported by the Swedish Environmental Protection Agency

(Naturvårdsverket) under Grant NV-06586-13; and Skåne Regional Council (Region Skåne) under Grant M066/2013.

\section{Notes}

1. The official name of the municipality is Malmö City, despite a large part of the municipal area is rural. Since the term city could be misleading, we use the term Malmö municipality or only Malmö throughout the text. 
2. This interpretation was made in close collaboration with Malmö municipality. The municipality is responsive to international policies through international contacts and projects within the environmental field.

\section{References}

Beery, T., Stålhammar, S., Jönsson, K. I., Wamsler, C., Bramryd, T., Brink, E., ... Schubert P. (2016). Perceptions of the ecosystem services concept: Opportunities and challenges in the Swedish municipal context. Ecosystem Services, 17, 123-130. doi:

10.1016/j.ecoser.2015.12.002

Bryman, A., (2012). Social Research Methods. Oxford: Oxford University Press.

Böck, K., Muhar, S., Muhar, A., \& Polt, R. (2015). The ecosystem services concept - gaps between science and practice in river landscape management. GAIA, 24(1), 32-40. doi: 10.14512/gaia.24.1.8

Centre for Climate Adaptation (2015). Sweden - Coastal Erosion. Retrieved from http://www.climateadaptation.eu/sweden/coastal-erosion

Charmaz, K. (2006). Constructing grounded theory: A practical guide through qualitative analysis. London: Sage.

Charmaz, K. (2008). Grounded theory as an emergent method. In: S. N. Hesse-Biber \& P. Leavy (Eds.), Handbook of Emergent Methods. New York: The Guilford Press. 
Daily, G. C. (1997). Introduction: What are ecosystem services? In: G. C. Daily (Ed.), Nature's Services: Societal Dependence of Ecosystems. Washington, D. C.: Island Press.

de Groot, R. S., Alkemade, R., Braat, L., Hein, L., \& Willemen, L. (2010). Challenges in integrating the concept of ecosystem services and values in landscape planning, management and decision making. Ecological Complexity, 7, 260-272.

Elmqvist, T., Setälä, H., Handel, S. N., van der Ploeg, S., Aronson, J., Blignaut, J. N., ... de Groot, R. (2015). Benefits of restoring ecosystem services in urban areas. Current Opinion in Environmental Sustainability, 14, 101-108. doi: 10.1016/j.cosust.2015.05.001

Environmental Programme (2009). Environmental programme for the city of Malmö 20092020. Malmö, Sweden: Malmö City Council.

Fahrig, L., (2002). Effect of habitat fragmentation on the extinction threshold: a synthesis. Ecological Applications, 12(2), 346-353. doi: 10.2307/3060946

Folke, C., Jansson, Å., Larsson, J., \& Costanza R., (1997). Ecosystem appropriation by cities. Ambio, 26(3), 167-172.

Government bill (1995). Regeringens Proposition 1994/1995:230 - Kommunal översiktsplanering enligt plan- och bygglagen, m.m. Stockholm: The Swedish Parliament.

Green Plan (2003). Green plan for Malmö 2003 - Summary. Malmö, Sweden: Malmö City. 
Gupta, J. (2015). Global governance of ecosystem services and related policy instruments. In:

J. A. Bouma \& P. J. H. van Beukering (Eds.), Ecosystem Services: From Concept to Practice. Cambridge: Cambridge University Press.

Haase, D., Larondelle, N., Andersson, E., Artmann, M., Borgström, S., Breuste, J., ...

Elmqvist, T. (2014). A quantitative review of urban ecosystem service assessments: Concepts, models, and implementation. Ambio, 43, 413-433. doi: 10.1007/s13280-014-0504-0

Hansen, R., Frantzeskaki, N., McPhearson, T., Rall, E., Kabisch, N., Kaczorowska, A., ... Pauleit, S. (2015). The uptake of the ecosystem services concept in planning discourses of European and American cities. Ecosystem Services, 12, 228-246. doi:

10.1016/j.ecoser.2014.11.013

Hanson, H., Hesslekrans, Å., Lidgren, J., Person, A., Westerberg, A., Remin Ström, M., ... Tillgren, J. (2016). BEST rapporten - Får ekosystemtjänster stöd i PBL? Malmö, Sweden: Malmö City and National Board of Housing, Building and Planning.

Hauck, J., Görg, C., Varjopuro, R., Ratamäki, O., \& Jax, K., (2013). Benefits and limitations of the ecosystem services concept in environmental policy and decision making: Some stakeholder perspectives. Environmental Science \& Policy, 25, 13-21. doi: 10.1016/j.envsci.2012.08.001

HELCOM (2009). Biodiversity in the Baltic Sea - An integrated thematic assessment on biodiversity and nature conservation in the Baltic Sea. Baltic Sea Environmental Proceedings. No. 116B. Helsinki, Finland: Helsinki Commission. 
Helliwell, D. R. (1969). Valuation of wildlife resources. Regional Studies, 3(1), 41-47. doi: $10.1080 / 09595236900185051$

Jönsson, K. I., Ekelund, N., Wamsler, C., Brink, E., Beery, T., Palo, T. R., ... Johansson, M. (2017). Implementering av ekosystemtjänstbegreppet i kommunal verksamhet.

Forskningssatsningen Värdet av ekosystemtjänster, Report 6755, Stockholm, Sweden: Swedish Environmental Protection Agency.

Kruuse, A. (2011). GRaBS Expert Paper 6: The Green Space Factor and the Green Points System. London: Town and Country Planning Association.

Larondelle, N., Haase, D., \& Kabisch, N. (2014). Mapping the diversity of regulating ecosystem services in European cities. Global Environmental Change, 26, 119-129. doi: 10.1016/j.gloenvcha.2014.04.008

Larson, M., \& Hanson, H. (2013). Sweden. In: E. Pranzini \& A. T. Williams (Eds.), Coastal Erosion and Protection in Europe. New York: Routledge.

Lenhart, J., Bouteligier, S., Mol, A. PJ., \& Kern, K. (2014). Cities as learning organisations in climate policy: the case of Malmö. International Journal of Urban Sustainable Development, 6(1), 89-106. doi: 10.1080/19463138.2014.889020

Loreau, M., \& de Mazancourt, C. (2013). Biodiversity and ecosystem stability: a synthesis of underlying mechanisms. Ecology Letters, 16, 106-115. doi: 10.1111/ele.12073 
Luederitz, C., Brink, E., Gralla, F., Hermelingmeier, V., Meyer, M., Niven, L., ... von Wehrden, H. (2015). A review of urban ecosystem services: Six key challenges for future research. Ecosystem Services, 14, 98-112. doi: 10.1016/j.ecoser.2015.05.001

Millennium Ecosystem Assessment (2005). Ecosystems and human well-being - Synthesis.

Washington, D. C.: Island Press.

Malmö City (n.d.). Handlingsplan för klimatanpassning Malmö 2012-2014. Malmö, Sweden: Malmö City.

Malmö City (2016a). Befolkningsprognos. Retrieved from

http://malmo.se/kommunpolitik/faktaochstatistik/befolkning/befolkningsprognos.4.4cc94c381 $\underline{5 b e 8 c d 0 d 0 b 1 f 365 . h t m l}$

Malmö City (2016b). Utmärkelser och priser. Retrieved from http://malmo.se/Kommun-politik/Studiebesok/Utmarkelser-och-priser.html

Mascarenhas, A., Ramos, T. B., Haase, D., \& Santos, R. (2014). Integration of ecosystem services in spatial planning: a survey on regional planners' views. Landscape Ecology, 29(8), 1287-1300. doi: 10.1007/s10980-014-0012-4

Matzdorf, B., \& Meyer, C. (2014). The relevance of the ecosystem services framework for developed countries' environmental policies: a comparative case study of the US and EU. Land Use Policy, 38, 509-521. doi: 10.1016/j.landusepol.2013.12.011 
McKenzie, E., Posner, S., Tillmann, P., Bernhardt, J. R., Howard, K., \& Rosenthal, A. (2014). Understanding the use of ecosystem service knowledge in decision making - lessons from international experiences of spatial planning. Environment and Planning C: Government and Policy, 32, 320-340. doi:10.1068/c12292j

Moghaddam, A. (2006). Coding issues in grounded theory. Issues In Educational Research, 16. Retrieved from http://www.iier.org.au/iier16/moghaddam.html

Niemelä, J., Saarela, S-R., Söderman, T., Kopperoinen, L., Yli-Pelkonen, V., Väre, S., \& Kotze, D. J. (2010). Using the ecosystem services approach for better planning and conservation of urban green spaces: A Finland case study. Biodiversity and Conservation, 19, 3225-3243. doi: 10.1007/s10531-010-9888-8

Panagopoulos, T., Duque, J. A. G., \& Dan, M. B. (2016). Urban planning with respect to environmental quality and human well-being. Environmental Pollution, 208, 137-144. doi: 10.1016/j.envpol.2015.07.038

Portman, M. E. (2013). Ecosystem services in practice: Challenges to real world implementation of ecosystem services across multiple landscapes - A critical review. Applied Geography, 45, 185-192.

Rauhut, D. (2008). Potential Nordic population 2030. Retrieved from http://www.nordregio.se/en/Metameny/About-Nordregio/Journal-of-Nordregio/2008/Journalof-Nordregio-no-1-2008/Potential-Nordic-population-2030 
Roberts, D. (2010). Prioritizing climate change adaptation and local level resilience in

Durban, South Africa. Environment \& Urbanization, 22(2), 397-413. doi:

$10.1177 / 0956247810379948$

Ryther, J. H. (1969). Photosynthesis and fish production in the sea. Science, 166(3901), 7276. doi: $10.1126 /$ science. 166.3901 .72

Sandström, U. G. (2002). Green infrastructure planning in urban Sweden. Planning Practice \& Research, 17(4), 373-385. doi: 10.1080/02697450216356

Sandström, U. G., Angelstam, P., \& Khakee, A. (2006). Urban comprehensive planning identifying barriers for the maintenance of functional habitat networks. Landscape and Planning, 75, 43-57. doi: 10.1016/j.landurbplan.2004.11.016

Swedish Government Official Reports (1994). 36 Miljö och fysisk planering (Environment and Physical Planning). Stockholm: The Swedish Government.

Swedish Government Official Reports (2013). 68 Synliggöra värdet av ekosystemtjänster (Highlighting the value of ecosystem services). Stockholm: The Swedish Government.

The Economics of Ecosystems and Biodiversity (2016). The Economics of Ecosystems and Biodiversity (TEEB). Retrieved from http://www.teebweb.org/

The Swedish Environmental Protection Agency (2015). Sweden's Environmental Objectives An Introduction. Stockholm: The Swedish Environmental Protection Agency. 
The World Bank (2016). Urban Development. Retrieved from

http://data.worldbank.org/topic/urban-development

UN-Habitat (2012). State of the World's Cities 2012/2013: Prosperity of Cities. New York:

Routledge.

Vignola, R., Locatelli, B., Martinez, C., \& Imbach, P. (2009). Ecosystem-based adaptation to climate change: what role for policy-makers, society and scientists? Mitigation and Adaptation Strategies for Global Change, 14(8), 691-696. doi: 10.1007/s11027-009-9193-6

Wallace, K. J. (2007). Classification of ecosystem services: problems and solutions. Biological Conservation, 139(3-4), 235-246. doi: 10.1016/j.biocon.2007.07.015

Wamsler, C. (2015). Mainstreaming ecosystem-based adaptation: Transformation toward sustainability in urban governance and planning. Ecology and Society, 20(2), 30. doi: 10.5751/ES-07489-200230

Wamsler, C., Luederitz, C., \& Brink, E. (2014). Local levers for change: Mainstreaming ecosystem-based adaptation into municipal planning to foster sustainability transitions. Global Environmental Change, 29, 189-201. doi: 10.1016/j.gloenvcha.2014.09.008

Wamsler, C., Niven, L., Beery, T. H., Bramryd, T., Ekelund, N., Jönsson, K. I., ... Stålhammar, S. (2016). Operationalizing ecosystem-based adaptation: Harnessing ecosystem services to buffer communities against climate change. Ecology and Society, 21(1), 31. doi: 10.5751/ES-08266-210131 
Wilkinson, C., Saarne, T., Peterson, G. D., \& Colding, J. (2013). Strategic spatial planning and the ecosystem services concept - an historical exploration. Ecology and Society, 18, 37. doi: 10.5751/ES-05368-180137

\section{Appendix A}

Semi-structured interview questions:

1. Have you come in contact with the concept of ecosystem services before you received the letter from us?

2. How does the ecosystem services concept compare with other concepts you come in contact with?

3. Do you consider the ecosystem services concept to be useful?

4. What are your impressions of the Swedish national interim goal of ecosystem services implementation at the municipal level?

5. How can we capture the value of ecosystem services?

6. How can the implementation of the ecosystem services concept change processes, outputs, and potential in the future? 


\section{Figures}

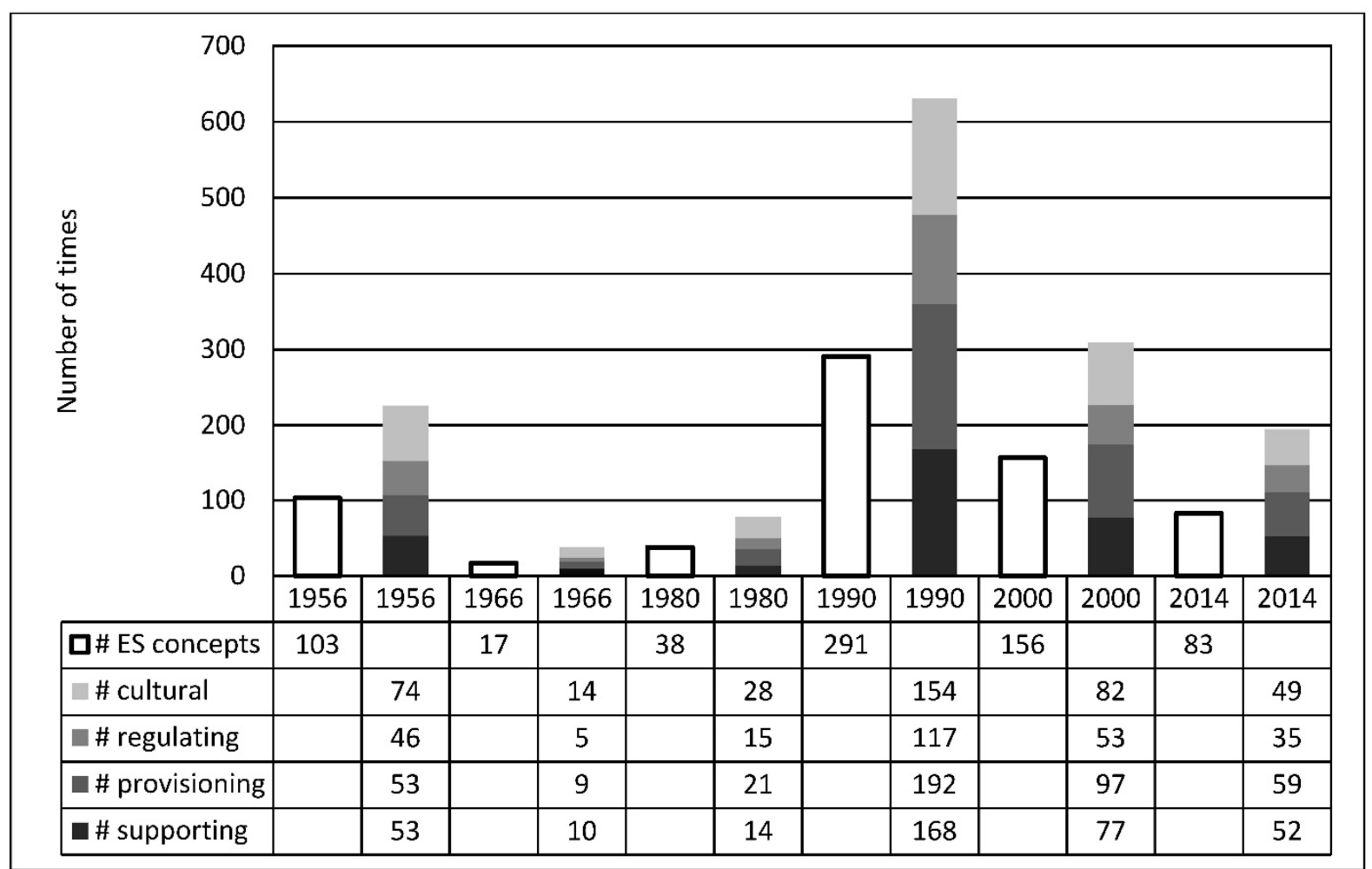

Figure 1. Numbers of ecosystem services (ES)-related concepts in Malmö municipality's comprehensive plans over the period 1956-2014. For each year, the left bar shows the result for all ES categories combined, while the right bar shows the results for individual ES categories. The table below the graph shows the actual data behind the bars. Note that the classification of a concept into the ES categories was nonexclusive, allowing a concept to be classified into more than one category at the same time. 


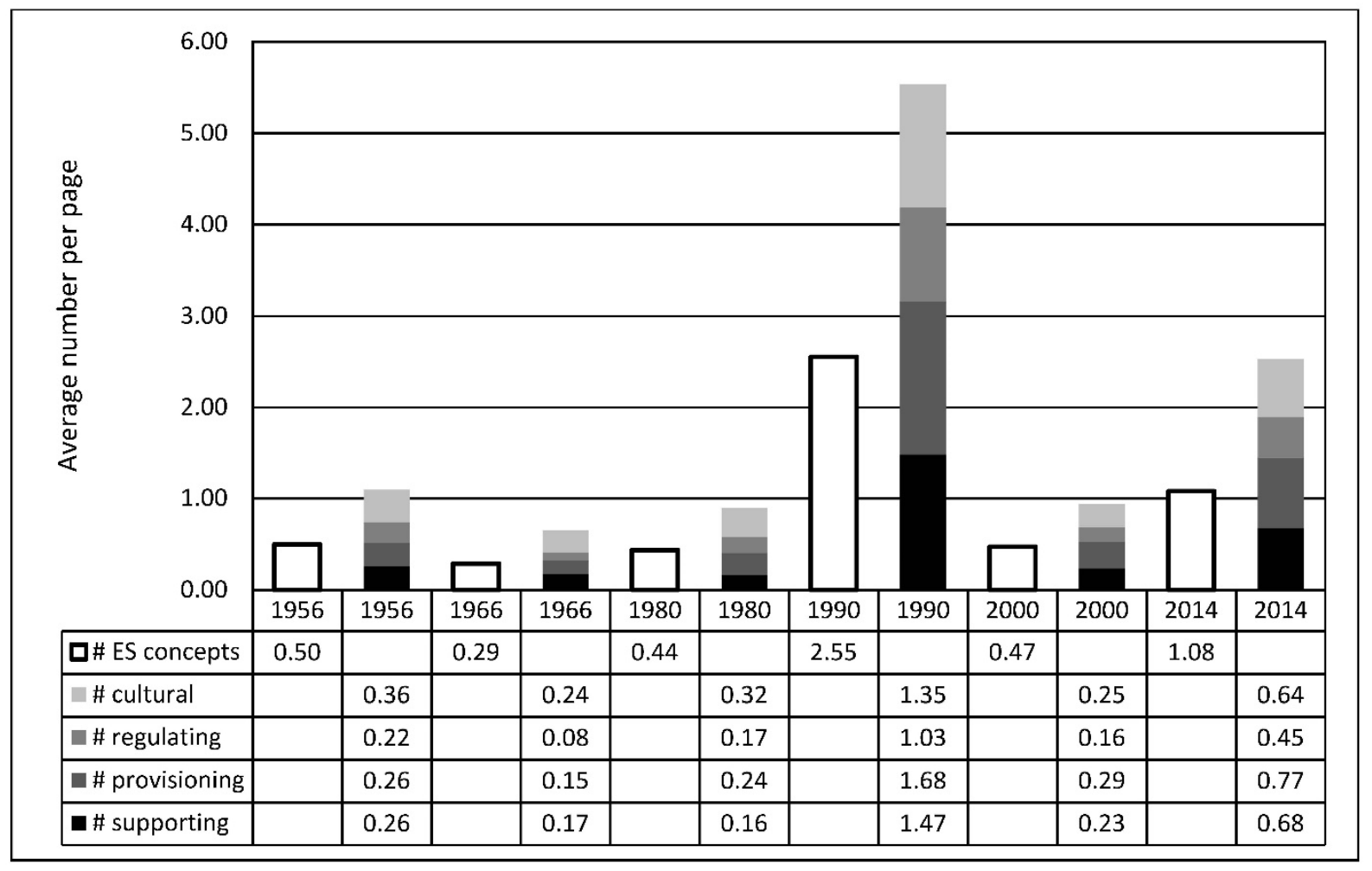

Figure 2. Average numbers of ecosystem services (ES)-related concepts per page in Malmö municipality's comprehensive plans over the period 1956-2014. For each year, the left bar shows the result for all ES categories combined, while the right bar shows result for individual ES categories. The table below the graph shows the actual data behind the bars. Note that the classification of a concept into the ES categories was nonexclusive, allowing a concept to be classified into more than one category at the same time. 


\section{Tables}

Table 1. Malmö comprehensive plans over the period 1956-2014. Swedish titles are within brackets.

\begin{tabular}{lcc}
\hline Comprehensive plan & Year & \# pages \\
\hline Comprehensive Plan for Malmö [Generalplan för Malmö] & 1956 & 207 \\
Comprehensive Plan for Malmö - Investigation 1966 [Generalplan för Malmö - & 1966 & 59 \\
Utredning 1966] & & \\
Comprehensive Plan for Malmö 1980 [Generalplan för Malmö 1980] & 1980 & 87 \\
Comprehensive Plan for Malmö 1990 [Översiktsplan för Malmö 1990] & 1990 & 114 \\
Comprehensive Plan for Malmö 2000 [Översiktsplan för Malmö 2000] & 2000 & 331 \\
Comprehensive Plan for Malmö - Planning Strategy [Översiktsplan för Malmö - & 2014 & 77 \\
Planstrategi] & &
\end{tabular}


Table 2. Examples from the 2014 comprehensive plan of ecosystem service (ES)-related concepts expressing supporting, provisioning, regulating, and/or cultural ES. Expressed ES are within brackets. Note that the classification of a concept into the ES categories was nonexclusive, allowing a concept to be classified into more than one category at the same time.

\begin{tabular}{|c|c|c|c|c|}
\hline Concept & Supporting & Provisioning & Regulating & Cultural \\
\hline Agricultural land & & $\mathrm{x}$ [food] & & $\mathrm{x}$ [aesthetic] \\
\hline Biomass & $\begin{array}{l}\mathrm{x} \text { [primary } \\
\text { production] }\end{array}$ & $x$ [food] & & \\
\hline Biogas production & & $\mathrm{x}$ [energy] & & \\
\hline Fishing & & $\mathrm{x}$ [food] & & $\begin{array}{l}\mathrm{x} \text { [cultural heritage, } \\
\text { recreation] }\end{array}$ \\
\hline Landscape scenery & & & & $\begin{array}{l}\mathrm{x} \text { [aesthetic, cultural } \\
\text { heritage, recreation] }\end{array}$ \\
\hline Nature & $\begin{array}{l}\text { x [e.g., nutrient } \\
\text { cycling, primary } \\
\text { production] }\end{array}$ & $\begin{array}{l}x \text { [e.g., food, fresh } \\
\text { water] }\end{array}$ & $\begin{array}{l}\text { x [e.g., climate } \\
\text { regulation, water } \\
\text { regulation] }\end{array}$ & $\begin{array}{l}x \text { [e.g., education, } \\
\text { recreation] }\end{array}$ \\
\hline Nature's values & $\mathrm{x}$ [same as nature] & $\mathrm{x}$ [same as nature] & $\mathrm{x}$ [same as nature] & $\mathrm{x}$ [same as nature] \\
\hline Recreation & & & & $\mathrm{x}$ [recreation] \\
\hline Recreation area & & & & $\mathrm{x}$ [same as recreation] \\
\hline Soil & x [soil formation] & $x$ [food] & & \\
\hline
\end{tabular}


Table 3. Ranking of the ecosystem service (ES) categories for each comprehensive plan, based on the average number of times per page each ES category is represented. Note that a higher ranking (i.e., a lower ranking value) corresponds to a higher average value, and that the shared ranking value 2.5 of supporting and provisioning services means that they have the same average value.

\begin{tabular}{lllll}
\hline Years & Supporting & Provisioning & Regulating & Cultural \\
\hline $\mathbf{1 9 5 6}$ & 2.5 & 2.5 & 4 & 1 \\
$\mathbf{1 9 6 6}$ & 2 & 3 & 4 & 1 \\
$\mathbf{1 9 8 0}$ & 4 & 2 & 3 & 1 \\
$\mathbf{1 9 9 0}$ & 2 & 1 & 4 & 3 \\
$\mathbf{2 0 0 0}$ & 3 & 1 & 4 & 2 \\
$\mathbf{2 0 1 4}$ & 2 & 1 & 4 & 3 \\
\hline Sum & 15.5 & 10.5 & 23 & 11 \\
\hline
\end{tabular}

Table 4. Recent programs where ecosystem services (ES) are explicitly expressed. Swedish titles are within brackets.

\begin{tabular}{ll}
\hline Program & Description \\
\hline Environmental Programme for the City of & Serves as a common basis for further \\
Malmö 2009-2020 [Miljöprogram för Malmö & environmental work within Malmö \\
stad 2009-2020] & $\begin{array}{l}\text { municipality. The focus of the program is on } \\
\text { the ecological aspect of the sustainability }\end{array}$ \\
& concept and takes responsibility for this part of \\
& the city's sustainability efforts. \\
Action Plan for the Environmental & Points out obligations where work must be \\
Programme - Prioritized Work in the City of & intensified to achieve the goals of the \\
Malmö 2015-2018 [Handlingsplan för & environmental program. \\
miljöprogrammet - prioriterat arbete i & \\
Malmö stad 2015-2018] & \\
\hline
\end{tabular}


Table 5. Recent projects where ecosystem services (ES) are explicitly expressed. Swedish titles are within brackets.

\begin{tabular}{|c|c|c|}
\hline Project & Years & Description \\
\hline BiodiverCity - About Green Inovation in the & $2012-2014$ & ES are perceived as added value of urban \\
\hline Urban Space [BiodiverCity - Om grön & & biodiversity, which is promoted by developing \\
\hline \multirow[t]{2}{*}{ innovation i det urbana rummet] } & & products, services, and processes for biological \\
\hline & & diversity. \\
\hline Mapping and Valuation of Ecosystem & 2013-2014 & Applies the TEEB six step model with the \\
\hline Services - Experiences of Using TEEB & & Riseberga brook as study case. Identifies \\
\hline [Kartläggning och värdering av & & stakeholders, lists ES, and explores the \\
\hline ekosystemtjänster - erfarenheter av att & & possibility of using economic valuation \\
\hline använda TEEB-metoden] & & methods. \\
\hline MEST_plan (Malmö Ecosystem Services) & 2014 & Investigates the possibilities of applying ES in \\
\hline \multirow[t]{2}{*}{ [MEST_plan (MalmöEkosSystemTjänster)] } & & planning processes to contribute to \\
\hline & & sustainability. \\
\hline BEST report (National Board of Planning & 2015-2016 & Examines how to involve ES in decision \\
\hline and Ecosystem Services) [BEST rapporten & & processes that are based on the Swedish \\
\hline (Boverket \& ekosystemtjänsterna)] & & planning and construction law. \\
\hline \multirow[t]{5}{*}{ Care of City [No Swedish title] } & 2014-2017 & Develops tools and methods to better account \\
\hline & & for ES in urban planning. The Stockholm \\
\hline & & city's project manager and environmental \\
\hline & & management is one of ten partners in the \\
\hline & & project. \\
\hline
\end{tabular}


Table 6. Discussion themes in relation to the content analysis and interview analysis results.

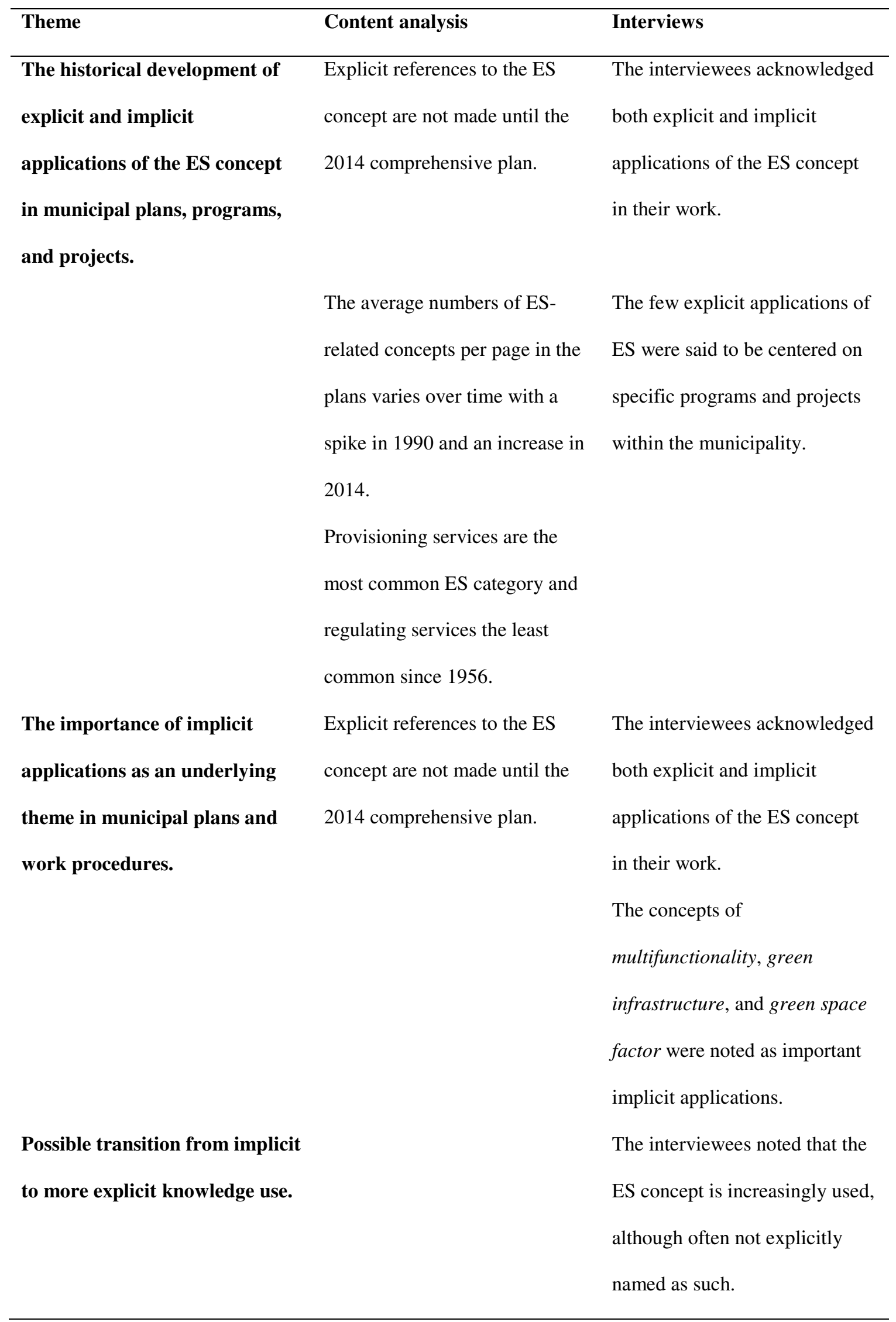

